\title{
An Evaluation of Partial Matrix Excision with Winograd Method for the Surgical Treatment of Ingrown Toenails
}

\author{
Tırnak Batması Cerrahi Tedavisinde Winograd Yöntemi ile Yapılan Kısmi Matriks Eksizyonu \\ Sonuçlarının Değerlendirilmesi
}

\author{
Olcay Güler ${ }^{1}$, Mahir Mahiroğulları', Serhat Mutlu², Halis Çerçi³, Ali Şeker ${ }^{1}$, Harun Mutlư \\ 1'Department of Orthopedy and Traumatology, Medipol University Faculty of Medicine, İstanbul, Turkey \\ ${ }^{2}$ Clinic of Orthopedy and Traumatology, Kanuni Sultan Süleyman Training and Research Hospital, İstanbul, Turkey \\ ${ }^{3}$ Clinic of Orthopedy and Traumatology, Private Nisa Hospital, i̇stanbul, Turkey \\ ${ }^{4} \mathrm{Clinic}$ of Orthopedy and Traumatology, Taksim Training and Research Hospital, İstanbul, Turkey
}

\begin{abstract}
Objective: The most frequent nail pathology of the hallux is the ingrown toenail. In our study, we evaluated Winograd's partial matrix excision method as a treatment for unilateral ingrown hallux toenail.

Methods: Winograd's partial toenail excision was performed on 239 patients (127 males, 112 females; mean age 37.4 years) with an ingrown toenail. Primary patient complaints included a painful hallux toenail, discharge, nail deformation, and difficulty walking. According to the Heifetz staging system, there were 62 patients evaluated as Stage I, 96 as Stage II, and 81 as Stage III. A total of 174 (74\%) patients had discharge from infection. In infected cases, an antibiotic was administered until inflammatory signs and discharged ceased, at which time surgical treatment was performed. Patients' duration to return to daily living and work, recurrence ratio, satisfaction, and cosmetic issues were evaluated. The mean follow-up time was 27 months (range: 14-45 months).
\end{abstract}

Results: Patients returned to daily living in 10-15 days (mean 11.3) and to work in 8.7 days (range: 6-13 days). A total of 230 patients (96.3\%) were satisfied with the procedure, and 231 patients (96.6\%) were satisfied with the cosmetic results. Nine patients were dissatisfied with the surgical outcome, and eight patients who experienced recurrence were dissatisfied with the cosmetic results. None of the patients experienced deep tissue infections or neurovascular complications.

Conclusion: Winograd's partial matrix excision method is a beneficial surgical procedure for ingrown toenail, resulting in low recurrence and high satisfaction rates. (JAREM 2014; 1: 7-11)

Key Words: Big toe, hallux, nail disorders, ingrown toenail surgery

\section{ÖZET}

Amaç: Tırnak batması, toplumda sık görülen ve en sık tırnak hastalığıdır. Bu çalışmada, ayak baş parmağına tek taraflı tırnak batması nedeniyle Winograd yöntemiyle kısmi matriks eksizyonu yapılan hastalarda tedavi sonuçları değerlendirildi.

Yöntemler: Tırnak batması nedeniyle 239 hastaya (127 erkek, 112 kadın; ort. yaş 37,4) Winograd prosedürüne uygun olarak kısmi matriks eksizyonu uygulandı. Hastaların temel şikayetleri ayak baş parmağına ağıı, akıntı, tırnakta şekil bozukluğu ve yürüme güçlüğü idi. Heifetz'in tırnak batması evrelendirmesine göre 62 hasta evre I, 96 hasta evre II, 81 hasta evre III olarak değerlendirildi. Yüz yetmiş sekiz (\%74) hastada enfeksiyon zemininde aktif akıntı vardı. Enfekte olgularda enflamasyon bulguları ve akıntı ortadan kalkıncaya kadar antibiyoterapi uygulandı ve sonrasında cerrahi tedavi yapıldı. Hastaların günlük hayat ve işe dönüş zamanları, nüks gelişme oranı, hasta memnuniyeti ve kozmetik sorunlar açısından değerlendirildi. Ortalama takip süresi 27 ay (dağılım 14-45 ay) idi.

Bulgular: Dokuz hastada (\%3,7) nüks görüldü. Ortalama nüks gelişim süresi 5,6 aydı (dağılım 2-9 ay). Hastalar ortalama 6,7 günde (dağılım 3-11 gün) günlük aktivitelerine geri döndü. İşe dönüş süresi ortalama 10,2 gün (dağılım 7-16 gün) bulundu. İkiyüzotuz (\%96,3) hasta yapılan müdahaleden memnundu. İki yüz otuz bir $(\% 96,6)$ hastada kozmetik olarak memnundu. Nüks gelişen hastaların dokuzu cerrahiden ve sekizi ise kozmetik açıdan memnun kalmadığını bildirdi. Hastaların hiçbirinde derin doku enfeksiyonu veya nörovasküler komplikasyon gelişmedi.

Sonuç: Tırnak batması tedavisinde Winograd yöntemiyle yapılan kısmi matriks eksizyonu nüks oranı düşük ve hasta memnuniyet oranı yüksek bir tedavi yöntemidir. (JAREM 2014; 1: 7-11)

Anahtar Sözcükler: Baş parmak, tırnak hastalığı, tırnak batması cerrahisi

\section{INTRODUCTION}

Ingrown toenails occur frequently and are the most common hallux toenail disease (1-3). There are many causes of ingrown toenails, including tight shoe wear and improper nail trimming. An ingrown toenail occurs as the nail grows into the nail bed (4). Complaints from patients with ingrown toenails include a dis- appearing nail, groove, soft tissue hypertrophy-related pain, an odorous discharge, and nail destruction. The nail groove is covered with a thin epidermal tissue layer. Normally, this layer prevents nail groove irritation. Wearing tight shoes or socks can increase the pressure on the nail and nail groove. Hyperplasia occurs as a result of irritation of the nail groove and the reaction 
of the surrounding soft tissues. Finally, the nail substance enters the nail groove and causes infection (5-10). Although there are many conservative and surgical treatments for ingrown toenails, the optimum treatment method has not been clearly defined because of the high recurrence rates, low degrees of patient satisfaction, and reported cosmetic issues.

In this study, we evaluated the partial matrix excision treatment for the unilateral ingrown hallux toenail.

\section{METHODS}

Partial matrix excision was performed on 239 patients (127 males, 112 females, mean age: 37.4 years, age range: $16-71$ years) who had a unilateral ingrown toenail from December 2008-October 2011. Fully informed consent was obtained from all patients. The ethics committee approved our study. Patients with onychomycosis were excluded from study after a dermatology consultation. Also, patients who had prior surgical treatment or bilateral or recurrent ingrown toenails and those who healed with conservative treatment were excluded. Radiography was not performed routinely. Major complaints included hallux pain, a foul-smelling discharge, and difficulty walking. Etiologies included inappropriate nail trimming (118 patients), narrow, tight footwear (28 patients), recurrent trauma (17 patients), and poor foot care (76 patients).

Patients were classified according to Heifetz's ingrown toenail classification system (11). This system classifies ingrowing toenails into the following three Stages: 1) Stage I: mild swelling, erythema, and tenderness along the lateral nail fold (inflammatory Stage), 2) Stage II: infection with active pus that was dependent on a bulged nail fold over the lateral nail plate edge (abscess Stage), and 3) Stage III: inhibition of free drainage by granulation tissue on the lateral nail fold (granulation Stage). During the first evaluation, 62 patients were classified as Stage I, 96 as Stage II, and 81 as Stage III. Infection-related active drainage was evident in 178 (74\%) patients. Prior to treatment with surgery, Stage I and II patients were advised to wear shoes with a wide and open forefoot box and to utilize warm foot baths. Silver nitrate was applied to the Stage III patients' ingrown toenails. In addition to the aforementioned conservative treatments, an oral, systemic, first-generation cephalosporin (cephalexin, $1 \mathrm{gr} /$ day in two doses) was prescribed to patients with infections before the surgical procedure. Bacteriological and fungal examinations were not performed. Surgical treatment was indicated for patients who did not benefit from conservative treatment.

\section{Surgical Technique}

The surgical procedure was performed on 239 patients after administration of digital anesthesia using $20 \mathrm{mg} / \mathrm{mL}$ prilocaine $\mathrm{HCl}$ and with use of a digital tourniquet. A colored (different from skin) tourniquet was used or a clamp was fixed to the tourniquet for identification (Figure 1). Winograd's partial matrix excision procedure was performed on all patients. A vertical incision was made through the nail plate on the ingrown side with a 15 blade. The incision included the length of the nail bed up to $4-5 \mathrm{~mm}$ proximal to the nail-skin border. The proximal aspect of the nail bed was excised with an oblique incision. Hypertrophied soft tissue covering the nail groove was excised through to the nail bed margin (Figure 2). Care was taken to prevent interphalangeal articulation and extensor tendon damage. All white-colored germinal matrix located near the nail fold was excised. The matrix on the distal phalanx cortex was curetted, and polypropylene sutures were placed in the skin edges (Figure 3). A pressurized dressing was applied, and the foot was elevated. Patients were prescribed non-steroidal antiinflammatory drugs and antibiotics (cephalexin $1 \mathrm{gr} /$ day in two doses). The dressings were changed every 2 days, and the sutures were removed after 2 weeks. Patients were evaluated at 6-month

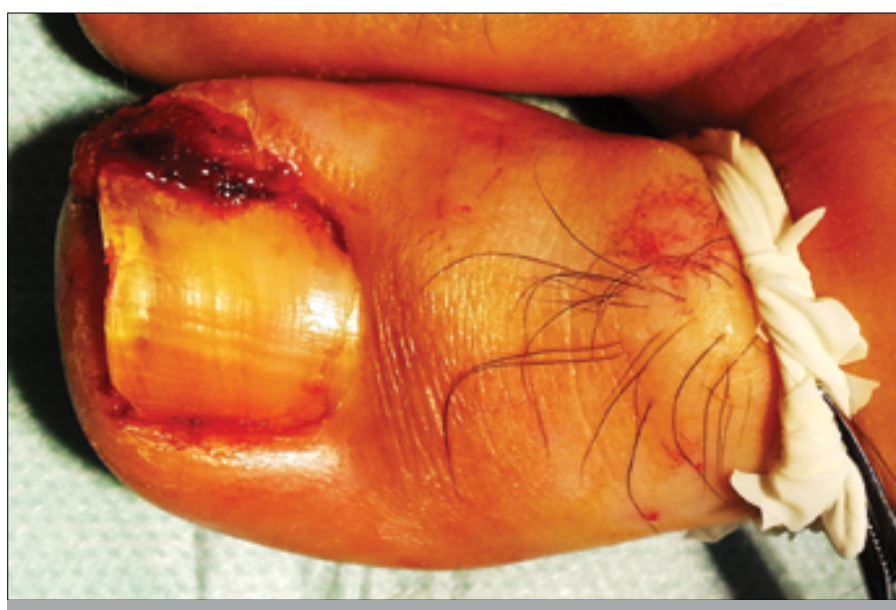

Figure 1. Preoperative preparation

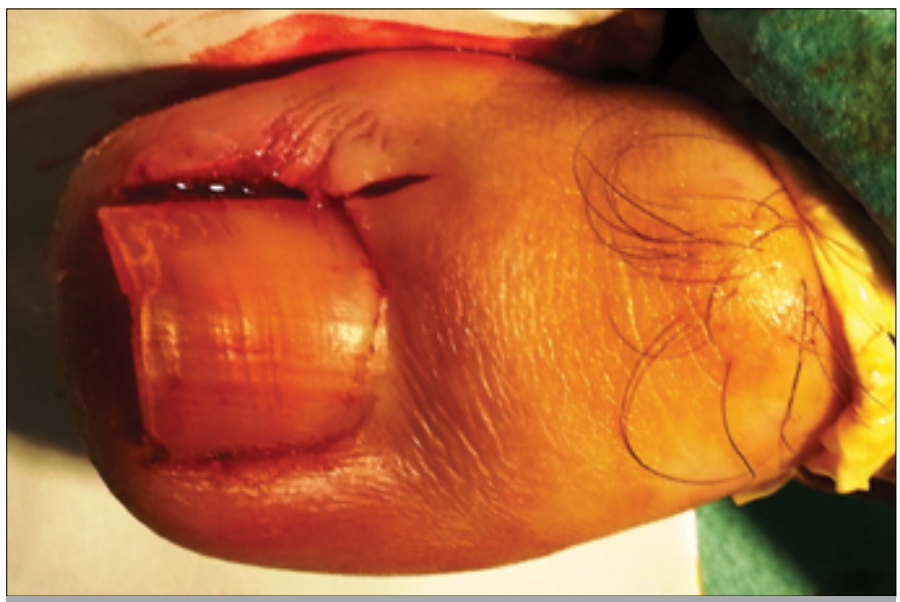

Figure 2. Winograd's partial matrix excision procedure

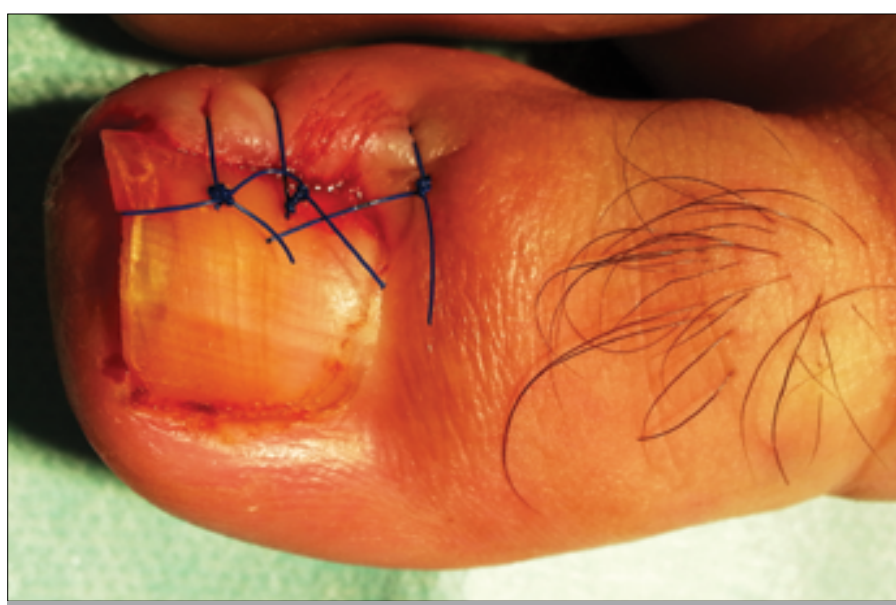

Figure 3. Postoperative appearance 
intervals. Time periods until return to daily living, return to work, and recurrence were recorded. Patients were asked if they would undergo the same surgical procedure it they had another ingrown toenail and were also were asked about their overall satisfaction and if they had any cosmetic issues. The mean follow-up time was 27 months (range: 14-45 months).

\section{RESULTS}

There were no reports of neurological or vascular complications, nor any deep tissue infections or osteomyelitis. Recurrence occurred in $3.7 \%$ of patients (four females, five males). The mean recurrence time was 5.6 months (range: 2-9 months). Of those cases of recurrence, three were Stage I, five were Stage II, and six were Stage III. Revision surgery was performed for recurrent cases, and after an average of 14 months, no cases of recurrence were reported.

Patients without recurrence returned their daily activities without any symptoms. The mean times until returning to daily living and work were 11.3 days (range: 10-15 days) and 8.7 days (range 6-13 days), respectively.

A total of 230 patients (96.3\%) were satisfied with the procedure. Each of the nine patients who were not satisfied had experienced recurrence and undergone revision surgery. The majority of patients $(231 ; 966 \%)$ was satisfied with the cosmetic results. Of the eight patients who were not, six had revision surgery after recurrence. All patients had complaints of a narrowed nail.

\section{DISCUSSION}

Ingrown toenail is common nail pathology. The hallux is most commonly affected toe. It is believed that both habitual and anatomical factors are involved in the etiology of ingrown toenail. While a congenital, thick nail substance is a predisposing anatomical factor, improper nail trimming, tight footwear, recurrent trauma, poor foot care, and hyperhidrosis are also involved in ingrown toenail development $(12,13)$. In our study, 118 patients exercised inappropriate nail trimming; 28 wore narrow, tight footwear; 17 had a history of recurrent trauma; and 76 patients practiced improper foot care.

Several theories have been suggested regarding ingrown toenail etiology involving the nail itself or the soft tissue surrounding the nail (14-16). The patient experiences pain and swelling and may notice granulation tissue, depending on the penetration of the nail rim into the soft tissues (17). That penetration causes an inflammatory response and frequently results in the formation of bulge at the nail rim (18).

Contrarily, the wider medial and lateral soft tissue of the hallux may cause the pathology instead of the nail. According to this theory, the wider load creates pressure, which in turn causes necrosis and inflammation that induce the ingrown toenail (16, 19). Pearson et al. (20) reported no nail abnormalities in symptomatic patients with ingrown toenails in a prospective study. They concluded that treatment should not be related to nail abnormalities. However, others believe nail abnormalities to be the primary factor in ingrown toenails, and controversy remains regarding whether nail abnormalities or ingrown nail folds are the cause.
Ingrown toenail may also result from osseous malformation of the dorsal surface of the distal phalanx or rough thickening of the nail as a consequence of a fungal infection of the nail bed. Trauma, paronychia, onycholysis, and fungal infections should be considered differential diagnoses in ingrown toenails and thoroughly investigated. In our study, any patients with a suspicion of nail malformation or fungal infection were evaluated by a dermatologist and excluded. In these cases, maintaining focus on the possible predisposing factors is suggested.

There are various conservative and surgical treatments for ingrown toenail $(21,22)$. Although the effectiveness of conservative treatments, such as footwear with an open and wide toe, warm foot baths, bandaging, administration of antibiotics, the use of the corrugated splint technique, or cotton seton, has not yet been demonstrated, these treatments continue to be suggested as the standard of care for mild and moderate ingrown toenail cases $(5,21,22)$. For our Stage I and II patients, footwear with an open and wide toe, warm footbaths, and antibiotics were used prior to surgery. Silver nitrate was applied to Stage III patients. Surgical treatment was performed in patients who did not benefit from conservative treatment.

Surgery can easily be performed under local anesthesia. A digital tourniquet made from a surgical glove should be applied. At the end of the surgery, the tourniquet must be removed and not be forgotten, as this could cause serious complications (5). To prevent this oversight, we suggest using a different colored surgical glove or attaching a clamp as a reminder. In our study, we used both blue surgical gloves and a clamp.

Surgical techniques may incorporate the following: 1) partial nail substance excision, 2) nail bed and nail matrix partial excision, 3) nail matrix chemical ablation, 4) soft tissue excision with nail bed and nail matrix treatment, or 4) only soft tissue excision $(11,22)$.

Resection and ablation techniques aim at the germinal matrix, which provides nail growth, thereby preventing regeneration of the nail. However, this method can cause cosmetic issues, depending on the level of matricectomy. Also, new nail spicules can form, and recurrence is possible if matricectomy is performed inadequately $(11,22)$.

Partial nail substance excision is performed on unilateral Stages I and II ingrown toenails without granulation tissue. After this procedure, patients quickly return to their daily activities and wear wide casual shoes. However, the recurrence rate of this procedure can reach $70 \%$ (22).

In 1936, Winograd determined that both the nail bed and nail matrix curettage should be used in ingrown toenail treatment (11). This method is a relatively easy and standardized surgical technique. The advantage of this technique is that no specialized chemicals or surgical equipment is needed. However, Kose et al. (23) reported that patients who had partial matrix excision with Winograd's technique complained of a narrowed nail substance with a proximal incision scar. Isik et al. (24) compared the partial matrix excision with a combined treatment (partial matrix excisionphenol application). Although no significant differences in duration of time to return to daily activities, postoperative pain, or recurrence rate were detected, the treatment cost and surgical 
durations were higher in the combined treatment group. The recurrence rate was $92 \%$ in the partial matrix excision group. In other studies, the recurrence rate of Winograd's procedure was $1.7-27 \%(4,5,11,23-25)$.

Procedures involving partial nail substance excision and chemical ablation of the germinal matrix gained popularity in 1945 . For chemical ablation, $80-88 \%$ phenol, 100\% trichloroacetic acid (TCA), or $10 \%$ sodium hydroxide $(\mathrm{NaOH})$ can be used. The recurrence rate after phenol ablation is reported to be $5 \%$. Complications included soft tissue necrosis, corrosion, drainage lasting $>6$ weeks, and rare systemic toxicity $(22,26-28)$.

Similar local complications, such as efflux and soft tissue necrosis, occurred after chemical ablation of the matrix with TCA or $\mathrm{NaOH}$. However, the success rates of these treatments were 95\% (22, 29-31). There are not yet enough controlled clinical trials to evaluate these treatments fully. On the other hand, matricectomy can be performed using a carbon dioxide $\left(\mathrm{CO}_{2}\right)$ laser, radiofrequency, and electrocautery. Success rates for matricectomy with a $\mathrm{CO}_{2}$ laser have been reported to be $50-100 \%$. It also has advantages, such as decreased postoperative hemorrhage and pain, as well as limited effects on the surrounding soft tissue. Several deleterious effects have been reported, including delayed epithelialization and prolonged soft tissue healing, lasting 3-6 weeks after the procedure $(22,32-34)$. There is no standard application time, technique, or chemical matricectomy procedure. Evolution of this technique could not prevent recurrence.

\section{CONCLUSION}

In our study, there was a $5.8 \%$ recurrence rate in patients who underwent the partial matrix excision procedure. Recurrence included development of nail spicules, which is related to inadequate matrix excision. In all cases of recurrence, revision surgery was performed with Winograd's technique, and new recurrence was not detected. A total of $96 \%$ of our patients expressed treatment satisfaction. All cases who were not satisfied were patients who had experienced recurrence and undergone revision surgery. All eight patients with cosmetic complaints had undergone revision surgery, which resulted in a narrowed nail substance. There was no continuous drainage, soft tissue necrosis, or wound problem in any patient. We believe that those complications are related to postoperative care and wound dressing changes. Dressing changes were performed every 2 days by the surgeon who performed the surgical procedures.

The learning curve of the partial matrix excision is steep. In this study, satisfactory results were achieved in terms of return to daily activity and work in patients who underwent Winograd's technique. Winograd's technique with partial matrix excision is a simple, cost-effective, and safe procedure with a low complication rate for patients who do not respond to conservative treatments for ingrown toenail.

Ethics Committee Approval: Ethics committee approval was not received due to the retrospective nature of the study.

Informed Consent: Written informed consent was obtained from patients who participated in this study.

Author Contributions: Concept - O.G., S.M.; Design - H.M., H.Ç.; Supervision - M.M., A.Ş.; Funding - O.G., H.M.; Materials - O.G., S.M.; Data Collection and/or Processing - H.Ç., H.M.; Analysis and/or Interpretation -
M.M., S.M.; Literature Review - H.M., A.Ş.; Writing - O.G., S.M.; Critical Review - M.M., A.Ş.; Other - O.G.,H.Ç.

Conflict of Interest: No conflict of interest was declared by the authors.

Financial Disclosure: The authors declared that this study has received no financial support.

Etik Komite Onayı: Çalışmanın retrospektif tasarımından dolayı etik komite onayı alınmamıştır.

Hasta Onamı: Yazılı hasta onamı bu çalışmaya katılan hastalardan alınmıştır.

Hakem Değerlendirmesi: Dış bağımsız.

Yazar Katkıları: Fikir - O.G., S.M.; Tasarım - H.M., H.Ç.; Denetleme - M.M., A.Ş.; Kaynaklar - O.G., H.M.; Malzemeler - O.G., S.M.; Veri toplanması ve/ veya işlemesi - H.Ç., H.M.; Analiz ve/veya yorum - M.M., S.M.;Literatür taraması - H.M., A.Ş.; Yazıyı yazan - O.G., S.M.; Eleştirel İnceleme - M.M., A.Ş.; Diğer - O.G.,H.Ç.

Çıkar Çatışması: Yazarlar herhangi bir çıkar çatışması bildirmemişlerdir.

Finansal Destek: Yazarlar bu çalışma için finansal destek almadıklarını beyan etmişlerdir.

\section{REFERENCES}

1. Murtagh J. Patient education. Ingrowing toenails. Australian family physician 1993; 22: 206.

2. Siegle RJ, Stewart R. Recalcitrant ingrowing nails: surgical approaches," Journal of Dermatologic Surgery and Oncology 1992; 744-52. [CrossRef]

3. Byrne DS, Caldwell D. Phenol cauterization for ingrowing toenails: A review of five years' experience. British Journal of Surgery 1989; 76: 598-9. [CrossRef]

4. Herold N, Houshian S, Riegels-Nielsen P. A prospective comparison of wedge matrix resection with nail matrix phenolization for the treatment of ingrown toenail. J Foot Ankle Surg 2001; 40: 390-5. [CrossRef]

5. Aydin N, Kocaoğlu B, Esemenli T. Partial removal of nail matrix in the treatment of ingrowing toe nail. Acta Orthop Traumatol Turc 2008; 42: 174-7. [CrossRef]

6. Heidelbaugh JJ, Lee $\mathrm{H}$. Management of the ingrown toenail. Am Fam Physician 2009; 79: 303-8.

7. Chapeskie H, Kovac JR. Case Series: Soft-tissue nail-fold excision: a definitive treatment for ingrown toenails. Can J Surg 2010; 53: 282-6.

8. Rounding $\mathrm{C}$, Bloomfield S. Surgical treatments for ingrowing toenails. Cochrane Database Syst Rev 2005; 18: CD001541.

9. Vaccari S, Dika E, Balestri R, Rech G, Piraccini BM,Fanti PA. Partial excision of matrix and phenolic ablation for the treatment of ingrowing toenail: a 36-month follow-up of 197 treated patients Dermatol Surg 2010; 36: 1288-93. [CrossRef]

10. Kruijff S, van Det RJ, van der Meer GT, van den Berg IC, van der Palen J, Geelkerken RH. Partial matrix excision or orthonyxia for ingrowing toenails.J Am Coll Surg 2008; 206: 148-53. [CrossRef]

11. The Foot and Ankle, Disorders of Nails and Skin, In: Campbell's operative orthopaedics. 11. Edition, Volume four, Mosby-Elsevier; 2008.p.4762-3.

12. Shaikh FM, Jafri M, Giri SK, Keane R. Efficacy of wedge resection with phenolization in the treatment of ingrowing toenails. J Am Podiatr Med Assoc 2008; 98: 118-22. [CrossRef]

13. Ikard RW. Onychocryptosis. J Am Coll Surg 1998; 187: 96-102. [CrossRef]

14. Lathrop RG. Ingrowing toenails: Causes and treatment. Cutis 1977; 20: 19-22.

15. Rounding C, Bloomfield S. Surgical treatments for ingrowing toenails. Cochrane Database Syst Rev 2005; 18: CD001541. 
16. Chapeskie H. Ingrown toenail or overgrown toe skin? Alternative treatment for onychocryptosis. Can Fam Physician 2008; 54: 1561-2.

17. Baran R, Haneke E, Richert B. Pincer nails: Definition and surgical treatment. Dermatol Surg 2001; 27: 261-6. [CrossRef]

18. De Berker DA, Baran R. Disorders of nails. In: Burns T, Breathnach SM, Cox N, Griffiths C, editors. Rook's Textbook of Dermatology. 8 th ed. Oxford: Wiley-Blackwell; 2004.p.65.

19. Langford DT, Burke C, Robertson K. Risk factors in onychocryptosis. Br J Surg 1989; 76: 45-8. [CrossRef]

20. Pearson HJ, Bury RN, Wapples J, Watkin DF. Ingrowing toenails: Is there a nail abnormality? A prospective study. J Bone Joint Surg $\mathrm{Br}$ 1987; 69: 840-2.

21. Haneke E. Controversies in the treatment of ingrown nails. Dermatol Res Pract.2012;2012:783924

22. Khunger N, Kandhari R. Ingrown toenails. Indian J Dermatol Venereol Leprol 2012; 78: 279-89. [CrossRef]

23. Kose O, Guler F, Gurcan S, Arik HO, Baz AB, Akalin S. Cosmetic results of wedge resection of nail matrix (Winograd technique) in the treatment of ingrown toenail. Foot Ankle Spec 2012; 5: 241-4. [CrossRef]

24. Isik C, Cakici H, Cagri Kose K, Goksugur N. Comparison of partial matrixectomy and combination treatment (partial matrixectomy +phenol) in ingrown toenail. Med Glas Ljek komore Zenicko-doboj kantona 2013; 10: 81-5.

25. Kayalar M, Bal E, Toros T, Ozaksar K, Gürbüz Y, Ademoğlu Y. Results of partial matrixectomy for chronic ingrown toenail. Foot Ankle Int 2011; 32: 888-95. [CrossRef]
26. Moossavi M, Scher RK. Complications of nail surgery: A review of the literature. Dermatol Surg 2001; 27: 225-8. [CrossRef]

27. Aksakal AB, Atahan C, Ozta P, Oruk S. Minimizing postoperative drainage with $20 \%$ ferric chloride after chemical matricectomy with phenol. Dermatol Surg 2001; 27: 158-60. [CrossRef]

28. Toybenshlak M, Elishoov O, London E, Akopnick I, Leibner DE. Major complications of minor surgery. J Bone Joint Surg Br 2005; 87: 1681-3. [CrossRef]

29. Ozdemir E, Bostanci S, Ekmekci P, Gurgey E. Chemical matricectomy with $10 \%$ sodium hydroxide for the treatment of ingrowing toenails. Dermatol Surg 2004; 30: 26-31. [CrossRef]

30. Tatlican S, Eren C, Yamangokturk B, Eskioglu F, Bostanci S. Chemical matricectomy with $10 \%$ sodium hydroxide for the treatment of ingrown toenails in people with diabetes. Dermatol Surg 2010; 36: 219-22. [CrossRef]

31. Kim SH, Ko HC, Oh CK, Kwon KS, Kim MB. Trichloroacetic acid matricectomy in the treatment of ingrowing toenails. Dermatol Surg 2009; 35: 973-9. [CrossRef]

32. Andre P. Ingrowing nails and carbon dioxide laser surgery. J Eur Acad Dermatol Venereol 2003; 17: 288-90. [CrossRef]

33. Lin YC, Su HY. A surgical approach to ingrown nail: Partial matricectomy using CO2 laser. DermatolSurg 2002; 28: 578-80. [CrossRef]

34. Leshin B, Whitaker DC. Carbon dioxide laser matricectomy. J Dermatol Surg Oncol 1988; 14: 608-11. [CrossRef] 